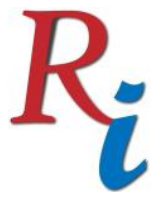

Asia Proceedings of Social Sciences

(APSS)

www.readersinsight.net/APSS

\title{
AN EMPIRICAL INVESTIGATION OF THE RELATIONSHIP BETWEEN POLITICAL SYSTEM AND ECONOMIC GROWTH IN POOR COUNTRIES LIKE PAKISTAN
}

\section{Muhammad Meraj ${ }^{*}$}

Department of Finance and Economics,

Faculty of Business Administration and Social Sciences,

Mohammad Ali Jinnah University, Karachi,

Pakistan,

m.meraj@jinnah.edu,mairu22@hotmail.com

\section{Ghulam Rasool Lakhan}

Department of Economics,

Federal Urdu University of Science Arts and Technology, Karachi,

Pakistan.

Glakhan1962@gmail.com

*Corrosponding author's Email: m.meraj@jinnah.edu, mairu22@hotmail.com

Peer-review under responsibility of $5 t^{d}$ Asia International Conference 2019 Scientific Committee http://connectingasia.org/scientific-committee/

(C) 2019 Published by Readers Insight Publisher, lat 306 Savoy Residencia, Block 3 F11/1,44000 Islamabad. Pakistan,

editor@readersinsight.net

This is an open access article under the CC BY-NC-ND license (http://creativecommons.org/licenses/by-nc-nd/4.0/). 


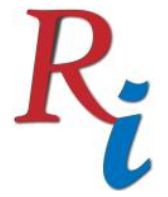

\section{Asia Proceedings of Social Sciences}

(APSS)

www.readersinsight.net/APSS

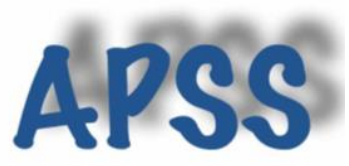

\section{A b s t r a c t}

Pakistan is an Islamic republic country where political situation is always on a roller coaster drive. The rivalry for dominance between military establishment and politicians negatively affected the ailing economy. Being a developing country, political institutions are not strong enough to handle a bumpy ride of governance. Politicians as well as the people of Pakistan always look forward towards military in both political and non-political disasters. In this context, we tried to unveil the relationship between the style of governance and development in this paper. Our results indicate that economic growth was much higher in non-democratic governments. Also, it shows the importance of institutional strength for the development of any country because the military is one of the strongest institutions in Pakistan. It is proposed that other sociopolitical institutions must get strength just like our military and work together to achieve sustainable economic growth that is a main ingredient of development for any country.

\section{Rese a r ch H igh I ight s}

This research revealed that the political system is an important factor for the economic growth of the poor countries like Pakistan. Solid and strong sociopolitical institutions play a vital role in the process of economic development especially in least developed countries where chances of misuse of authority is higher. It also unveils the weaknesses of political fraternity in the process of economic development due to a lack of institutional strength which provides an open ground for the non-democratic forces to intervene in the political processes. The military in Pakistan is a strongest institution and always works for the betterment of the country. The history of Islamic Republic of Pakistan shows that the military not only helps in borders and security front but in political process too whenever need arises. During the military regime in Pakistan the pace of economic growth was much faster than the democracy.

\section{Research Objectives}

The main objective of this research is to investigate the causal link between the political governance and economic growth in Pakistan. Our aim is to unveil the importance of political 


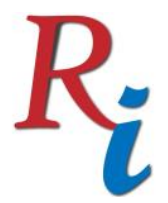

\section{Asia Proceedings of Social Sciences}

(APSS)

www.readersinsight.net/APSS

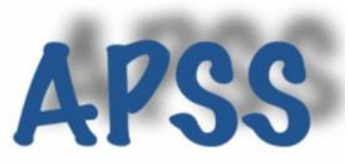

system in the process of sustainable economic developing in poor countries like Pakistan. It can be considered a timely effort because the history of political system in Pakistan shows that the military ruled the country for a period of time which is almost equal to the period of democracy, so the theme of this paper is to understand why the politicians or political governments keep failing in the seventy-two years' history of Pakistan. What were the mistakes they keep committing and paid the price of their mistakes and why they provided a chance to military to intervene in the political process or governance.

\section{Methodology}

To investigate the relationship between political leadership and economic growth, a number of diversified indices were developed in this paper. Political sustainability index is a composite index, designed to capture the joint effects. Augmented Human development index (AHDI) is created by keeping in mind the conventional human development index (HDI) which was developed by the renowned Pakistani Economist, Dr. Mehboob Ul Haq. The economic index is developed on the guidelines of traditional HDI. In the education index, we use primary education as a proxy rather than using the education enrolment ratio and adult literacy rate because the definition of literate in the Islamic Republic of Pakistan is quite novice. According to National Literacy Policies, the one who can just read and write 3 lines is counted as a literate (NLP, 2015). The foreign inflow index (FII) is developed to investigate the position of foreign inflows in the country by summing up three indicators i.e. remittances inflows, official development assistance and foreign direct investment. Trade openness index (TOI) is developed to capture the effects of trade enhancement because if the economy is on growth track the exports could be used as an engine of growth. Investment index is designed in consideration with the conditions for investment. It is pertinent that investment is considered a backbone of economic growth i.e. a significantly higher investment stimulates the economy to grow steadily. The government expenditures are also included as a second factor in this index.

\section{Results}

Five different models are used to investigate the impact of political governance on economic growth of poor countries like Pakistan. The empirical results suggest that political leadership 


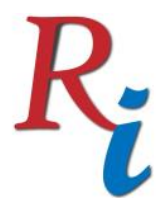

\section{Asia Proceedings of Social Sciences}

(APSS)

www.readersinsight.net/APSS

has some significant impacts on economic growth. The first model exhibits a significant increase in AHDI during democratic governments than military regimes with the possibility of democratic governance's significant focus on health and education. The empirical results came through the investment index show a significant decline in the investment during the periods of democracy than military regimes. The declining value of composite index of political stability or political sustainability (PSI) indicates that the democratic government were not upto the task of sustainable economic development in Pakistan. One of the factors of underperformance of political governments might be the continuous threats of throne change and a situation of political anarchy during the periods of democracy in Pakistan.

\section{Findings}

The political governance in Pakistan has always been instable thoughout its history. A continuous rift between the democractic and non-democratic forces did not allow the country to achive a significant economic growth. A continuous change of leadership makes the sociopolitical instutions weaker which is one of the factors of their under performance. It is worthwhile to note that political leadership in Pakistan is drastically failed to achieve the longrun goals of sustainable economic growth or human development which allows the military to internve and achieve the economic targets, that was actually the task assigned to the political leadership by the constitution of Pakistan.

\section{References}

National Literacy Policies of Pakistan. 2015. Source: http://www.accu.or.jp/litdbase/policy/pak/ (accessed on October 12, 2019).

\section{Author's Biography}

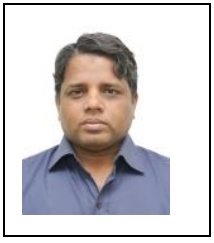

Dr. Muhammad Meraj is a renowened economist who has completed his doctorate from Ritsumeikan Asia Pacific University (APU), Japan. He finished his MA (Economics), M.B.A (Finance) and MA (Islamic History) from 


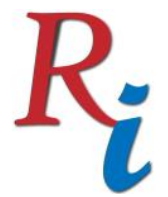

\section{Asia Proceedings of Social Sciences}

(APSS)

www.readersinsight.net/APSS

Karachi, Pakistan. Currently he is serving in Mohammad Ali Jinnah University (MAJU), Karachi, Pakistan, in both academics and research. He is an active member of research community in Pakistan and awarded the status of Higher Education Commission of Pakistan's approved Ph.D Supervisor. He has published a number of research papers and participated in many international research conferences.

Dr. Ghulam Rasool Lakhan is an academian and researcher. Presently he is serving as the head, department of econmics in Federal Urdu University of Arts Science and Technology in Karachi Pakistan. He has also served as the dean of the said university in Karachi Pakistan. He has more than eighteen research publication on his credentials. His areas of expertise are statistical analysis, eonometric testing, demographic transition, and development economics. 